This is an open access article distributed under the terms of the Creative Commons BY-NC-ND Licence

\title{
The effects of gibberellic acid on Allium cepa root tip meristematic cells
}

\author{
B. TÜTÜNOĞLU1 ${ }^{1}$ Ö. AKSOY ${ }^{1 *}$, R. ÖZBEK ${ }^{2}$, and F. UÇKAN ${ }^{1}$ \\ Department of Biology, Faculty of Science and Literature, University of Kocaeli, Kocaeli, 41380, Turkey ${ }^{1}$ \\ Fraunhofer Institute for Molecular Biology and Applied Ecology, Department of Bioresources, \\ Giessen, 35394, Germany²
}

\begin{abstract}
Gibberellic acid (GA) is a natural plant growth regulator (PGR) which stimulates germination, vegetative growth, flowering, and fruit formation. However, when high concentrations of GA are used, it inhibits plant growth and development and causes abnormalities in the plant tissue. In our study, we determined the effects of different concentrations of GA on Allium cepa L. var. cepa roots. Increasing concentrations of GA $\left(50-5000 \mathrm{mg} \mathrm{dm}^{-3}\right) \mathrm{were}^{-}$ used in $A$. серa root growth inhibition tests. Further, random amplified polymorphic DNA technique was used for determination of possible genotoxic effects of $600-1200 \mathrm{mg} \mathrm{dm}^{-3} \mathrm{GA}$ on $A$. cepa root tips. Our findings show cytotoxic and genotoxic effects of these concentrations of GA and indicate that the difference among control and treatment groups were statistically significant.
\end{abstract}

Additional key words: genomic template stability, growth inhibition test, mitotic index, onion, RAPD.

\section{Introduction}

Plant growth regulators (PGRs) regulate many of the physiological and developmental processes of agronomic importance. Gibberellic acid (GA), which is a tetracyclic di-terpenoid fungal chemical, is the most frequently produced in commercial industrial scale fermentations of Gibberella. The GA also plays important roles in many cellular processes including seed germination, transitions from juvenile to adult leaf stage, vegetative stage to flowering, fruit formation, and grain development (Celik et al. 2008). The amount of this hormone spread to the environment may soon exceed those of some pesticides (Tuluce and Celik 2006). During seed germination, embryonic GA is released and this triggers weakening the seed cover by stimulating gene expression involved in cell expansion and modification as reported in Arabidopsis (Finkelstein et al. 2008). During seed germination, GA stimulate the production of hydrolytic enzymes, e.g., $\alpha$-amylase in the aleuron layer of germinating cereal grains (Yamauchi et al. 2004, Seo et al. 2009). In this layer, GA also triggers the programmed cell death in combination with reactive oxygen species.
Expression of many genes regulated by GA and abscisic acid has been identified in barley (Gómez-Cadenas et al. 2001). Mutation in a gene encoding a hetero-trimeric GA protein impairs GA signaling in aleurone cells and causes a dwarf phenotype in rice (Ueguchi-Tanaka et al. 2000). Though GA is synthesized in plastids, it is translocated to different regions of the plant body through sieve tubes by an active translocation mechanism (Karl and Turgeon 1999).

Although GA is known to promote plant growth and development, there are several reports about the genotoxicity of GA on some organisms (Uçkan et al. 2008). Data obtained from the early ecological studies indicate that GA has no potential risks to agricultural plants and does not likely cause adverse effects in nontarget organisms. These studies suggested that due to the lack of acute toxicity, it should be placed in toxicity categories III (slightly toxic) and IV (nontoxic) and does not require any additional evaluation regarding non-target organism exposure. However, based on recent studies, the Pesticide Action Network of North America (PANNA)

Submitted 19 July 2018, last revision 14 November 2018, accepted 15 November 2018.

Abbreviations: GA - gibberellic acid; GTS - genomic template stability; MI - mitotic index; PGR - plant growth regulator; RAPD random amplified polymorphic DNA.

Acknowledgements: This study is a part of the MSc. Thesis "Determination of the cytotoxic and genotoxic effects of gibberellic acid on Allium cepa L. var. cepa (Alliaceae)" and supported by the project Kocaeli BAP-2014-020. We would like to thank Dr. Orhan Aksoy for his contributions to the article revision.

* Corresponding author; e-mail: odalgic@yahoo.com 
database suggests that possible GA acute toxicity, carcinogenicity, ground water contaminating characteristics, and developmental or reproductive toxicity should be reevaluated (Boğa et al. 2009).

Random amplified polymorphic DNA (RAPD) is a PCR based and quite reproducible technique that yields information on a large number of markers without having to obtain DNA sequence information for primer design (Agarwal et al. 2008). Many scientists used RAPD PCR technique for a variety of purposes, such as cultivar identification, genetic diversity assessment, and the construction of phylogenetic relationships (Aksoy et al. 2013, Özen et al. 2016), and it has been successfully

\section{Materials and methods}

Plants and EC50 determination: The commercial bulbs of Allium cepa L. var. cepa were germinated in Erlenmeyer flasks containing distilled water at a temperature of $25 \pm 2{ }^{\circ} \mathrm{C}$ in the dark for $48 \mathrm{~h}$ and their primary root length reached $1-2 \mathrm{~cm}$. Then they were treated with 9 different concentrations of GA $(50,100$, $150,200,300,500,600,1200$, and $5000 \mathrm{mg} \mathrm{dm}^{-3}$ ) for 24 , 48 , and $72 \mathrm{~h}$ to determine the effective concentration $\left(\mathrm{EC}_{50}\right)$. These concentrations were selected on the basis of root growth inhibition tests (Rucińska et al. 1999). Considering control root length as a standard, root lengths of treated bulbs were plotted against concentrations and the point showing $50 \%$ growth was designated as an $\mathrm{EC}_{50}$ concentration (Chauhan et al. 1999). The average value of $\mathrm{EC}_{50}$ that lowers root growth by $50 \%$ was calculated as $600 \mathrm{mg} \mathrm{dm}^{-3} \mathrm{GA}$. For the further experiments $2 \times \mathrm{EC}_{50}\left(1200 \mathrm{mg} \mathrm{dm}^{-3}\right), \mathrm{EC}_{50}$ $\left(600 \mathrm{mg} \mathrm{dm}^{-3}\right)$ and $\mathrm{EC}_{50} / 2\left(300 \mathrm{mg} \mathrm{dm}^{-3}\right)$ concentrations of GA were used.

Mitotic index analysis: After 72-h GA treatment, root tips were fixed in a Carnoy solution (3:1, ethyl alcohol:acetic acid) and hydrolyzed in $1 \mathrm{M} \mathrm{HCl}$ at $60{ }^{\circ} \mathrm{C}$ for $5-10$ min followed by squashing in a $2 \%(\mathrm{~m} / \mathrm{v})$ orcein stain in $45 \%(\mathrm{v} / \mathrm{v})$ acetic acid. Slides were examined immediately. The mitotic index (MI) was determined by examination of 1000 cells per slide. Three replicates were made for each GA concentration. To investigate abnormality percentages (chromosomal bridges, lagging chromosomes, chromosomal fragments, etc.) at different stages of mitosis, abnormal cells were counted, and the percentage of abnormal cells was determined in each phase (Aksoy and Deveci 2012).

Extraction of DNA and RAPD PCR technique: Germinated roots were collected after 72-h of GA treatment, grounded in liquid nitrogen, and total genomic DNA was extracted with a DNeasy plant mini kit (Qiagen, Valenvia, CA, USA). Twenty primers (Thermo Fisher Scientific, San Jose, CA, USA) were used for utilized in identification of genotoxicity of toxic chemicals (Cenkci et al. 2009). Although GA is used for a wide variety of crops, there are only few reports on toxicity screening GA using the RAPD or similar molecular marker techniques. The root meristematic tissues of $A$. cepa represent valuable and sensitive systems for the determination of the cytotoxic and genotoxic effects of several environmental pollutants (Majer et al. 2005). Thus, our study aimed to determine the effects of different concentrations of GA, which are widely used in agricultural and horticultural production, on $A$. cepa L. var. cepa roots.

RAPD analysis (10 of them were from OPA series and 10 from $\mathrm{AD}$ series). The sequences and Tm (primer melting temperature) values of OPA and AD series primers were given in Table 1 and 2 Suppl. Conditions for PCR were optimized according to Williams et al. 1990. The PCR was performed in a reaction mixture of $25 \mathrm{~mm}^{3}$ containing approximately $20 \mathrm{ng}$ of genomic DNA, $0.3 \mu \mathrm{M}$ primer, $20 \mu \mathrm{M}$ dNTPs, $25 \mathrm{mM} \mathrm{MgCl}_{2}, 1 \mathrm{U}$ of Taq DNA polymerase (Sigma, St. Louis, USA) and $1 \times$ reaction buffer containing $10 \mathrm{mM}$ Tris- $\mathrm{HCl}, 50 \mathrm{mM} \mathrm{KCl}$, $1.5 \mathrm{mM} \mathrm{MgCl}_{2}$ (New England Biolabs, MA, USA). The PCR program comprised an initial denaturation step at 98 ${ }^{\circ} \mathrm{C}$ for $1 \mathrm{~min}$ followed by 40 cycles at $98{ }^{\circ} \mathrm{C}$ for $30 \mathrm{~s}$ (denaturation), $34{ }^{\circ} \mathrm{C}$ for $20 \mathrm{~s}$ (annealing), and $72{ }^{\circ} \mathrm{C}$ for $30 \mathrm{~s}$ (extension), followed by a final extension at $72{ }^{\circ} \mathrm{C}$ for $30 \mathrm{~s}$. The amplification was carried out in triplicate. The PCR products and a 100-bp DNA ladder (Fermentas, Thermo Fisher Scientific) were resolved electrophoretically in $1 \%(\mathrm{~m} / \mathrm{v})$ agarose gels containing $0.5 \mu \mathrm{g} \mathrm{cm}^{-3}$ ethidium bromide and run at $90 \mathrm{~V}$ for about $1 \mathrm{~h}$. The molecular masses of the amplification products were calculated using 100-bp DNA ladder standards. The RAPD banding patterns were visualized using a UV transilluminator, and photo documentation was performed under UV radiation using a photo imaging system.

Genomic template stability (GTS) was calculated as GTS $[\%]=(1-\mathrm{a} / \mathrm{n}) \times 100$, where $\mathrm{a}$ is the RAPD polymorphic profile detected in each treated sample, and $\mathrm{n}$ is the number of total bands in the control. Polymorphism observed in RAPD profiles included disappearance of a normal band and appearance of a new band in comparison to the control RAPD profiles (Atienzar et al. 2002). The average was then calculated for each experimental group exposed to different GA treatments.

Amplicons (bands) were scored as 1 (presence) or 0 (absence). Only strong bands were scored for analysis. The size of each amplification product was automatically 
estimated using the Vision WorksLS v. 6.8; images were captured using a high-resolution scan, and digitalized images were counted directly for RAPD analysis. Genetic similarity coefficients (phenetic numerical analysis) among the roots of untreated control and treated roots were estimated from the Nei unbiased measure (Nei 1978) in POPGENE v. 1.31.

\section{Results}

Changes in germination percentages of $A$. cepa roots that were treated with different concentrations of GA for 24, 48 , and $72 \mathrm{~h}$ are given in Table 1 . The decreases in root lengths in all GA concentrations were statistically significant. By observing average root length percentages for different GA concentrations in $A$. cepa, the $\mathrm{EC}_{50}$ that increased the root length by $50 \%$ was found to be $600 \mathrm{mg} \mathrm{dm}^{-3}$; the GA concentrations used for the rest of the study were 300,600 , and $1200 \mathrm{mg} \mathrm{dm}^{-3}$ ), and the meristematic cells of $A$. cepa root tips were treated with different concentrations of GA for 24, 48, and $72 \mathrm{~h}$. Germination percentages after $72 \mathrm{~h}$ were 54, 50, and 26 $\%$ at GA concentrations of 300,600 , and $1200 \mathrm{mg} \mathrm{dm}^{-3}$, respectively.

Table 1. Changes in length [cm] of Allium cepa roots treated with different concentrations of gibberellic acid (GA) for 24, 48, and $72 \mathrm{~h}$. Means \pm SDs, $n=15$. Different letters mark significant differences at $P \leq 0.05$.

\begin{tabular}{rlll}
\hline $\begin{array}{l}\text { GA } \\
{\left[\mathrm{mg} \mathrm{dm}{ }^{-3}\right]}\end{array}$ & $24 \mathrm{~h}$ & $48 \mathrm{~h}$ & $72 \mathrm{~h}$ \\
\hline 0 & $0.74 \pm 0.03 \mathrm{a}$ & $1.43 \pm 0.11 \mathrm{a}$ & $2.24 \pm 0.09 \mathrm{a}$ \\
50 & $0.37 \pm 0.01 \mathrm{~b}$ & $0.87 \pm 0.05 \mathrm{bce}$ & $1.70 \pm 0.08 \mathrm{bc}$ \\
100 & $0.47 \pm 0.02 \mathrm{~cd}$ & $0.98 \pm 0.05 \mathrm{bcef}$ & $1.63 \pm 0.08 \mathrm{bc}$ \\
150 & $0.35 \pm 0.01 \mathrm{bef}$ & $0.87 \pm 0.04 \mathrm{bce}$ & $1.85 \pm 0.22 \mathrm{abc}$ \\
200 & $0.51 \pm 0.02 \mathrm{c}$ & $1.21 \pm 0.06 \mathrm{af}$ & $1.75 \pm 0.08 \mathrm{bc}$ \\
300 & $0.46 \pm 0.02 \mathrm{~cd}$ & $1.15 \pm 0.05 \mathrm{adf}$ & $1.68 \pm 0.09 \mathrm{bc}$ \\
500 & $0.47 \pm 0.02 \mathrm{~cd}$ & $0.95 \pm 0.05 \mathrm{bcde}$ & $1.37 \pm 0.08 \mathrm{~b}$ \\
600 & $0.40 \pm 0.01 \mathrm{bdef}$ & $0.86 \pm 0.03 \mathrm{ce}$ & $1.84 \pm 0.10 \mathrm{ac}$ \\
1200 & $0.48 \pm 0.02 \mathrm{~cd}$ & $1.10 \pm 0.05 \mathrm{ab}$ & $1.81 \pm 0.09 \mathrm{c}$ \\
5000 & $0.34 \pm 0.01 \mathrm{bf}$ & $0.75 \pm 0.04 \mathrm{c}$ & $1.57 \pm 0.09 \mathrm{bc}$ \\
\hline
\end{tabular}

Generally, MI decreased when the GA concentration increased (Table 2). At the highest (1 $200 \mathrm{mg} \mathrm{dm}^{-3}$ ) GA concentration, the percentage of germination was reduced from 90 to $26 \%$ and MI was reduced from 18.5 to 12.4 $\%$ when compared to the control group. After the treatment of $A$. cepa bulbs with the three concentrations of GA for $72 \mathrm{~h}$, MI of the control group was $19.27 \%$, whereas it decreased to $18.05 \%$ at $300 \mathrm{mg} \mathrm{dm}^{-3} \mathrm{GA}$, to $17.55 \%$ at $600 \mathrm{mg} \mathrm{dm}^{-3} \mathrm{GA}$, and to $12.66 \%$ at $1200 \mathrm{mg}$ $\mathrm{dm}^{-3}$ GA (Table 2). Thus, the lowest MI was observed in the treatment with $1200 \mathrm{mg} \mathrm{dm}^{-3} \mathrm{GA}$.
Statistical analysis: The statistical analysis of data was carried out using SPSS for Windows v. 16.0 (SPSS Inc, Chicago, USA). Statistically significant differences between the groups were compared using one-way analysis of variance (ANOVA) and the Duncan test. The $P$-values less than 0.05 were considered as statistically significant.

Table 2. The effects of different concentrations of gibberellic acid (GA) for $72 \mathrm{~h}$ on mitotic index in A. cepa root tips. Means \pm SDs, $n=15$, Means followed by different letters are significantly different at $\mathrm{P} \leq 0.05$.

\begin{tabular}{ll}
\hline GA concentration $\left[\mathrm{mg} \mathrm{dm}^{-3}\right]$ & Mitotic index [\%] \\
\hline 0 & $19.27 \pm 1.18 \mathrm{a}$ \\
300 & $18.05 \pm 2.35 \mathrm{ab}$ \\
600 & $17.55 \pm 1.34 \mathrm{ab}$ \\
1200 & $12.66 \pm 1.01 \mathrm{~b}$ \\
\hline
\end{tabular}

There were no significant differences between GA treatments and the control group at prophase and telophase, but there were significant differences at metaphase and anaphase (Table 3). However, chromosome aberrations were monitored at all phases of mitosis. The increase in the amount of abnormal cells was positively correlated with the increase in GA concentration. The recorded abnormalities were deformation of the cell wall, disturbed prophase, c-mitosis, polar slip, vagrant chromosome, stickiness, laggards, and chromosomal bridges. The occurrence of chromosomal abnormalities, cell death, and impairments in the cell membrane by GA has been indicated for the first time. As a result of the obtained findings, different concentrations of GA, especially $1200 \mathrm{mg} \mathrm{dm}^{-3} \mathrm{GA}$ treatment, might be a potential threat to the genetic material and cell structure of the A. cepa root tips.

The result of RAPD PCR screening A. cepa treated with different concentrations of GA showed that 18 primers had a polymorphic band profile and only 2 primers showed a monomorphic band profile when compared to the control group. Twenty 10-mer oligonucleotide primers of $60-70 \%$ GC content were utilized for screening the $A$. cepa genome for changes, and all of the primers generated specific and stable results. Eighteen RAPD profiles showed substantial differences between the untreated control and GA treated A. cepa with apparent changes (disappearance and/or appearance) in the number and size of amplified DNA fragments for different primers

The RAPD fingerprints showed substantial differences between control and GA treated root tips with apparent changes in the number, size, and visibility of 


\section{B. TÜTÜNOĞLU et al.}

Table 3. The effects of different concentrations of gibberellic acid (GA) for $72 \mathrm{~h}$ on the ratio of normal cells to abnormal cells in different phases of mitosis. Means \pm SDs, $n=15$, means followed by different letters a-c (normal cells) or x-z (abnormal cells) are significantly different at $P \leq 0.05$.

\begin{tabular}{cllll}
\hline GA $\left[\mathrm{mg} \mathrm{cm}^{-3}\right]$ & Prophase & Metaphase & Anaphase & Telophase \\
\hline 0 & $7.44 \pm 1.05 \mathrm{a} / 0.44 \pm 0.19 \mathrm{x}$ & $3.77 \pm 0.37 \mathrm{a} / 0.22 \pm 0.12 \mathrm{x}$ & $3.50 \pm 0.73 \mathrm{a} / 0.66 \pm 0.25 \mathrm{x}$ & $3.11 \pm 0.70 \mathrm{a} / 0.11 \pm 0.07 \mathrm{x}$ \\
300 & $5.61 \pm 1.12 \mathrm{a} / 1.11 \pm 0.39 \mathrm{xy}$ & $1.72 \pm 0.82 \mathrm{ab} / 2.66 \pm 0.55 \mathrm{y}$ & $2.33 \pm 0.62 \mathrm{ab} / 1.38 \pm 0.29 \mathrm{x}$ & $2.61 \pm 0.49 \mathrm{a} / 0.72 \pm 0.44 \mathrm{xy}$ \\
600 & $5.55 \pm 1.14 \mathrm{a} / 1.72 \pm 0.54 \mathrm{xyz}$ & $1.38 \pm 0.56 \mathrm{~b} / 2.44 \pm 0.37 \mathrm{y}$ & $1.11 \pm 0.45 \mathrm{~b} / 1.88 \pm 0.44 \mathrm{x}$ & $2.22 \pm 0.61 \mathrm{a} / 1.22 \pm 0.23 \mathrm{y}$ \\
1200 & $3.27 \pm 1.33 \mathrm{a} / 3.27 \pm 0.25 \mathrm{z}$ & $0.44 \pm 0.29 \mathrm{~b} / 1.22 \pm 0.33 \mathrm{xy}$ & $1.44 \pm 0.72 \mathrm{ab} / 1.11 \pm 0.43 \mathrm{x}$ & $1.66 \pm 0.50 \mathrm{a} / 0.22 \pm 0.16 \mathrm{x}$ \\
\hline
\end{tabular}

amplified DNA fragments. In all cases, polymorphisms were due to the loss and/or gain of the amplified bands in the treated samples. The value of polymorphism $\mathrm{P}$ was $8 \%$. The GTS values reflecting changes in RAPD profiles were calculated for 13 primers (Table 4). Some of the GTS values were lower at different GA concentrations when compared to the control group.

\section{Discussion}

The PGRs have various effects when applied at different concentrations to different plant organs and in various stages of plant growth (Kocaçalışkan 2003). Despite that PGRs are a valuable tool used in agriculture, they can be toxic if they are used in high concentrations. They accumulate in the soil and slowly decay.

Table 4. The effects of different concentrations of gibberellic acid (GA) for $72 \mathrm{~h}$ on genomic template stability [\%].

\begin{tabular}{|c|c|c|c|c|}
\hline \multirow[t]{2}{*}{ Primers } & \multicolumn{4}{|c|}{$\mathrm{GA}\left[\mathrm{mg} \mathrm{cm}^{-3}\right]$} \\
\hline & 0 & 300 & 600 & 1200 \\
\hline AD-02 & 100 & 67 & 67 & 100 \\
\hline AD-05 & 100 & 67 & 100 & 100 \\
\hline AD-07 & 100 & 100 & 75 & 75 \\
\hline AD-09 & 100 & 100 & 100 & 80 \\
\hline AD-10 & 100 & 100 & 50 & 50 \\
\hline OPA-01 & 100 & 100 & 100 & 80 \\
\hline OPA-02 & 100 & 100 & 80 & 80 \\
\hline OPA-03 & 100 & 100 & 0 & 100 \\
\hline OPA-04 & 100 & 67 & 100 & 100 \\
\hline OPA- 05 & 100 & 100 & 100 & 86 \\
\hline OPA-06 & 100 & 100 & 100 & 63 \\
\hline OPA-07 & 100 & 100 & 100 & 50 \\
\hline OPA-10 & 100 & 100 & 100 & 0 \\
\hline
\end{tabular}

The GA promotes the seed germination (Karssen et al. 1989, 1995, Sharma et al. 2004) by supporting the synthesis of $\alpha$-amylase and other hydrolytic enzymes (Fincher 1989). In the present experiments, we found that the percentage of root germination and MI decreased with increasing GA concentrations. The deterioration of mitotic configuration and formation of the irregular stages can be based on changes in the mechanism of chromosome movement or irregularity of their location in the equatorial plane (Soliman and Ghoneam 2004). We frequently observed a shift of the equatorial plane, chromosome bridges, and also c-mitosis as abnormalities due to increasing GA concentrations. Especially, treatment with $1200 \mathrm{mg} \mathrm{dm}^{-3}$ GA caused formation of c-mitosis so we concluded that the use of high doses of GA may be effective on microtubules. We thought that micronucleus formation may be caused by the formation of laggard chromosomes.

Alterations of DNA in a genome can clearly be shown by comparing RAPD PCR profiles of untreated and treated organisms (Atienzar and Jha 2006). The differences in RAPD profiles could also be used to estimate reduction in root growth, total soluble protein and chlorophyll content (Cenkci et al. 2010). As a result of structural changes or mutations in DNA (e.g., rearrangements, point mutations, small inserts or deletions of DNA, and ploidy changes), new sites become accessible to primers, and they can amplify new PCR products (Abdelmigid 2009).

The appearance or disappearance of bands can be considered as a symptom of the genotoxic effect of GA for onion roots. Some specific binding sites of genomic DNA may have become accessible to some oligonucleotide primers after structural modifications resulting from DNA damage. As a result of the analysis performed in our study, among 20 RAPD primers used, 18 of them produced polymorphic bands. Abbas et al. (2017) reported that similar trends of polymorphisms can be obtained in Phoenix dactylifera when using a high concentration of 2,4-dichlorphenoxyacetic acid.

In this study the genetic variations were induced by high concentrations of GA and this genetic variations could be caused by several mechanisms, such as the mutagenic activity (deletion or insertion mutation), DNA damage (single or double-strand breaks), chromosomal aberration (Abbas et al. 2017). 
After understanding the effects of PGRs on plant growth and development, synthetic production and commercial use of these substances have accelerated. As many of the herbicides consist of PGRs, the accumulation of these chemicals in the environment is a known fact and their effects on non-target organisms should be investigated and understood.

\section{References}

Abass, M.H., Al-Utbi, S.D., Al-Samir, E.A.R.H.: Genotoxicity assessment of high concentrations of 2,4-D, NAA and Dicamba on date palm callus (Phoenix dactylifera L.) using protein profile and RAPD markers. - J. Genet. Engn. Biotechnol. 15: 287-295, 2017.

Abdelmigid, H.M.: Risk assessment of food coloring agents on DNA damage using RAPD markers. - Open Biotechnol. J. 3: 96-102. 2009.

Agarwal, M., Shrivastava, N., Padh, H.: Advances in molecular marker techniques and their applications in plant sciences. Plant Cell Rep. 27: 617-631, 2008.

Aksoy, Ö., Deveci A.: The investigation of the cytotoxic effects of some pesticides on soybean (Glycine max L.). - Cytologia 77: 475-483, 2012.

Aksoy, Ö., Erbulucu, T., Özen, F., Deveci, A.: Genetic variation in critically endangered plant Amsonia orientalis Decne. - J. Biodiver. Environ. Sci. 3: 44-53. 2013.

Atienzar, F.A., Jha, A.N.: The random amplified polymorphic DNA (RAPD) assay and related techniques applied to genotoxicity and carcinogenesis studies: a critical review. Mutat. Res. Genet. Toxicol. 613: 76-102, 2006.

Atienzar, F.A., Veiner, P., Jha, A.N., Depledge, M.H.: Evaluation of the random amplified polymorphic DNA (RAPD) assay for the detection of DNA damage and mutations. - Mutat. Res. Genet. Toxicol. 521: 151-163, 2002.

Boğa, A., Binokay, S., Sertdemir, Y.: The toxicity and teratogenicity of gibberellic acid $\left(\mathrm{GA}_{3}\right)$ based on the frog embryo teratogenesis assay - Xenopus (FETAX). - Turk. J. Biol. 33: 181-188, 2009.

Chauhan, L.K.S., Saxena, P.N., Gupta, S.K.: Cytogenetic effects of cypermethrin and fenvalerate on the root meristem cells of Allium cepa. - Environ. exp. Bot. 42: 181189, 1999.

Celik, A., Unyayar, S., Cekic, F.O., Güzel, A.: Micronucleus frequency and lipid peroxidation in Allium sativum root tip cells treated with gibberellic acid and cadmium. - Cell Biol. Toxicol. 24: 159-164, 2008.

Cenkci, S., Ciğerci, Ġ.H., Yıldız, M., Ozay, C., Bozdağ, A., Terzi, H.: Lead contamination reduces chlorophyll biosynthesis and genomic template stability in Brassica rapa L. - Environ. exp. Bot. 67: 467-473, 2010.

Cenkci, S., Yıldız, M., Ciğerci, I.H., Konuk, M., Bozdağ, A.: Toxic chemicals-induced genotoxicity detected by random amplified polymorphic DNA (RAPD) in bean (Phaseolus vulgaris L.) seedlings. - Chemosphere 76: 900-906, 2009.

Fincher, G.B.: Molecular and cellular biology association with endosperm mobilization in germination cereal grains. Annu. Rev. Plant. Physiol. 40: 305-346, 1989.

Finkelstein, R., Reeves, W., Ariizumi, T., Steber, C.: Molecular aspects of seed dormancy. - Annu. Rev. Plant Biol. 59: 387415, 2008.

Gómez-Cadenas, A., Zentella, R., Walker-Simmons, M.K., Ho, T.H.: Gibberellin/abscisic acid antagonism in barley aleurone cells: site of action of the protein kinase PKABA1 in relation to gibberellin signaling molecules. - Plant Cell 13: 667-679, 2001.

Karl, J.O., Turgeon, R.: Sieve elements and companion cells traffic control centers of the phloem.- Plant Cell. 11: 739$750,1999$.

Karssen, C.M.: Hormonal regulation of seed development, dormancy and germination studied by genetic control. - In: Kigel, J., Golili, G. (ed.): Seed Development and Germination. Pp. 17-33. Marcel Dekker, New York 1995.

Karssen, C.M., Zagorski, S., Kepczynski, J., Groot, S.P.C.: Key role for endogenous gibberellins in the control of seed germination. - Ann. Bot. 63: 71-80, 1989.

Kocaçalı̧skan, İ.: Plant Physiology. Dumlupınar University, Faculty of Arts and Sciences Publications, Kütahya 2003.

Majer, B.J., Grummt, T., Uhi, M., Knasmuller, S.: Use of plant assay for the detection of genotoxins in the aquatic environment. - Acta. Hydrochem. Hydrobiol. 33: 45-55, 2005.

Nei, M.: Genetic distance between populations. - Amer. Natur. 106: 283-292, 1978.

Özen, F., Aka, G.E., Aksoy, Ö.: Genetic diversity and conservation strategies of some Lilium candidum L. populations in Turkey. - Bangladesh J. Bot. 45: 133-141, 2016.

Rucińska, R., Waplak, S., Gwóźdź, E.A.: Free radical formation and activity of antioxidant enzymes in lupin roots exposed to lead. - Plant Physiol. Biochem. 37: 187-194, 1999.

Seo, M., Nambara, E., Choi, G., Yamaguchi, S.: Interaction of light and hormone signals in germinating seeds. - Plant mol. Biol. 69: 463-472, 2009.

Sharma, A.D., Thakur, M., Rana, M., Singh, K.: Effect of Plant growth hormones and abiotic stresses on germination, growth and phosphatate activities in Sorghum biocolor (L.) Moench seeds. - Afr. J. Biotechnol. 3: 308-312, 2004.

Soliman, M.I., Ghoneam, G.T.: The mutagenic potentialities of some herbicides using Vicia faba as a biological system. Biotechnology 3: 140-154, 2004.

Tuluce, Y., Celik, I.: Influence of subacute and subchronic treatment of abcisic acid and gibberellic acid on serum marker enzymes and erythrocyte and tissue antioxidant defense systems and lipid peroxidation in rats. - Pestic. Biochem. Physiol. 86: 85-92, 2006.

Uçkan, F., Tüven, A., Er, A., Ergin, E.: Effects of gibberellic acid on biological parameters of the larval endoparasitoid Apanteles galleriae (Hymenoptera: Braconidae). - Ann. Entomol. Soc. Amer. 101: 593-597, 2008.

Ueguchi-Tanaka, M., Fujisawa, Y., Kobayashi, M., Ashikari, M., Iwasaki, Y., Kitano, H.: Rice dwarf mutant d1, which is defective in the alpha subunit of the heterotrimeric $G$ protein, affects gibberellin signal transduction. - Proc. nat. Acad. Sci. USA 97: 38-43, 2000.

Yamauchi, Y., Ogawa, M., Kuwahara, A., Hanada, A., Kamiya, Y., Yamaguchi, S.: Activation of gibberellin biosynthesis 
B. TÜTÜNOĞLU et al.

and response pathways by low temperature during imbibition of Arabidopsis thaliana seeds. - Plant Cell 16: 367-78, 2004.
Williams, J., Kubelik, A. R., Livak, K. J.: DNA polymorphisms amplified by arbitrary primers are useful as genetic markers. - Nucl. Acids Res. 18: 6531-6535, 1990. 